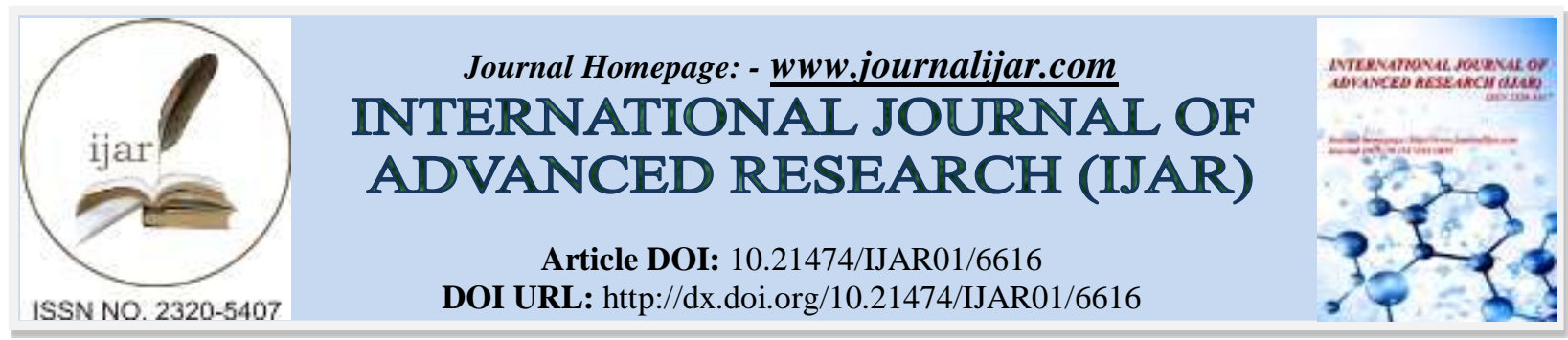

RESEARCH ARTICLE

\title{
BACTERIOLOGICAL STUDY OF VENTILATOR-ASSOCIATED PNEUMONIA IN A TERTIARY CARE HOSPITAL.
}

Dr. Trupti D. Satpute ${ }^{1}$ and Dr. Sunanda N. Shrikhande ${ }^{2}$.

1. Assistant Professor, Department of Microbiology, Government Medical College, Nagpur.

2. Professor \& Head, Department of Microbiology, Government Medical College, Nagpur.

\section{Manuscript Info}

Manuscript History

Received: 23 December 2017

Final Accepted: 25 January 2018

Published: February 2018

Key words:-

intensive care unit; extended

spectrum beta-lactamase; ampC-

beta-lactamase; metallo-beta-

lactamase.
Ventilator-associated pneumonia;

\begin{abstract}
Ventilator-associated pneumonia (VAP) is the most common nosocomial infection diagnosed in the intensive care units (ICUs). Microorganisms responsible for ventilator associated pneumonia vary from place to place. VAP requires a rapid diagnosis and initiation of the antibiotic treatment.The present study was carried out to detect bacteria commonly associated with VAP and determine their susceptibility patterns including beta-lactamases production. Out of a total 1438 patients intubated for more than 48 hours, 302 patients (21.0\%) were clinically diagnosed as VAP cases. The VAP rate was found to be 2.06 cases per 1000 ventilator days. A. baumannii (38.11\%), P. aeruginosa (26.74\%), K. pneumoniae (14.85\%), S.aureus (11.38\%), E. coli (3.96\%), C. freundii (1.98\%), A. lwoffi (1.98\%) and P. mirabilis $(0.99 \%)$ were isolated. Amongst the gram negative isolates, $15.64 \%$ were ESBL, $11.73 \%$ were AmpC and $13.96 \%$ were MBL producers. Early diagnosis of VAP along with their sensitivity pattern will help as an epidemiological marker for initial prophylaxis and treatment planning for mechanically ventilated patients.
\end{abstract}

Copy Right, IJAR, 2018,. All rights reserved.

\section{Introduction:-}

Ventilator-associated pneumonia (VAP) is the most common nosocomial infection diagnosed in the intensive care units (ICUs). ${ }^{1}$ It is defined as pneumonia occurring more than 48 hours after endotracheal intubation and initiation of mechanical ventilation (MV). ${ }^{2}$ VAP is the most frequent infection occurring in 9 to $24 \%$ of the intubated patients admitted in ICU., ${ }^{3,4}$ It has been associated with an attributable mortality of approximately $30 \%$ depending on the pathogen isolated, ${ }^{5,6}$ which may exceed $50 \%$. $^{7,8}$

Microorganisms responsible for ventilator associated pneumonia vary from place to place. Common pathogens include aerobic gram-negative bacilli (GNB), such as Pseudomonas aeruginosa, Escherichia coli, Klebsiella pneumoniae and Acinetobacter species; ${ }^{9}$ gram positive cocci such as Staphylococcus aureus. ${ }^{5}$

There have been reports of increased occurrence of multi-drug resistant pathogens including carbapenem resistance bacteria in health care settings in recent times.

To date, however, there are very few studies in India evaluating VAP. Thus, this study was carried out to detect the bacteria commonly associated with VAP and determine their susceptibility patterns. 


\section{Material and methods:-}

The present study was carried out at a tertiary care hospital and approved by the Ethical committee of Indira Gandhi Government Medical College, Nagpur.

During the two and a half year study period, a total of 1438 patients admitted to the ICUs were intubated for more than 48 hours. Out of them, 302 patients were clinically diagnosed to have VAP. Thus, patients on MV for more than 48 hours having temperature of $>38{ }^{\circ} \mathrm{C}$ or $<36{ }^{\circ} \mathrm{C}$, leukopenia or leukocytosis or having purulent tracheal secretions were included in the study.

Endotracheal tube aspirates were obtained with sterile precaution using a 22 inch No.14F suction catheter and collected in a mucous collector. ${ }^{10}$ The samples were processed and the isolates were identified by standard microbiological procedures. ${ }^{11}$ Antimicrobial susceptibility testing was done by Kirby-Bauer disk diffusion method ${ }^{10}$ as per CLSI guidelines. ${ }^{12}$

All the gram negative isolates (Enterobacteriaceae group, Acinetobacter spp. and P. aeruginosa) were tested for extended spectrum $\beta$-lactamases (ESBL) and AmpC $\beta$-lactamases production ${ }^{10,13}$ by initial screening and phenotypic confirmatory test (PCT) as per CLSI guidelines. ${ }^{10}$ ESBL production was detected by combined disk test using both cefotaxime and ceftazidime, alone and in combination with clavulanic acid, was performed. ${ }^{10}$ Amp $\mathrm{C}$ production was detected by AmpC disk test. ${ }^{14}$ Carbapenemases production in Enterobacteriaceae ${ }^{10}$ and non-fermentative gram negative $^{15}$ isolates were tested by performing both initial screening test and phenotypic confirmatory test (Modified Hodge test). MBL production was detected by minimum inhibitory concentration (MIC) testing by agar dilution method using meropenem; and MIC reduction testing using meropenem and meropenem-EDTA as per CLSI guidelines. $^{10,16,17} \mathrm{MBL}$ testing was also done using double disk synergy test (Imipenem, Meropenem and Ceftazidime). ${ }^{18,19}$

Methicillin resistant S. aureus (MRSA) production was detected by Cefoxitin disk diffusion testing ${ }^{10,20,21}$ and Minimum inhibitory concentration testing of oxacillin ${ }^{10,13,22}$ by agar dilution method using oxacillin-salt screen agar containing $6 \mu \mathrm{g} / \mathrm{ml}$ oxacillin and $4 \% \mathrm{NaCl}^{25}$

Statistical analysis

Data analysis was done by Chi square test with appropriate (yate's) correction to see the significance of difference using SPSS software; $\mathrm{p} \leq 0.05$ was considered significant.

Table I:- Bacteria isolated from VAP with antibiotic resistance pattern (\%) $(\mathrm{n}=302)$

\begin{tabular}{|c|c|c|c|c|c|c|c|c|c|c|c|c|c|c|c|}
\hline $\begin{array}{l}\text { Organis } \\
\text { ms (n) }\end{array}$ & $\begin{array}{l}\mathbf{A M} \\
\mathbf{P}\end{array}$ & $\begin{array}{l}\mathbf{A M} \\
\mathbf{C}\end{array}$ & $\begin{array}{l}\text { CA } \\
\mathbf{Z}\end{array}$ & $\begin{array}{l}\text { CT } \\
X \\
\end{array}$ & CX & $\begin{array}{l}\mathbf{C P} \\
\mathbf{M}\end{array}$ & PIT & $\begin{array}{l}\text { ME } \\
M\end{array}$ & $\begin{array}{l}\mathbf{G E} \\
\mathbf{N}\end{array}$ & $\begin{array}{l}\mathbf{A M} \\
\mathbf{K}\end{array}$ & $\begin{array}{l}\text { TE } \\
\mathbf{T}\end{array}$ & CIP & $\begin{array}{l}\text { CO } \\
\text { T }\end{array}$ & AT & $\begin{array}{l}* \mathbf{C} \\
\mathbf{L}\end{array}$ \\
\hline $\begin{array}{l}K . \\
\text { pneumon } \\
\text { iae (30) }\end{array}$ & 100 & 100 & $\begin{array}{l}96.6 \\
6\end{array}$ & $\begin{array}{l}86.6 \\
6\end{array}$ & $\begin{array}{l}76.6 \\
6\end{array}$ & $\begin{array}{l}83.3 \\
3\end{array}$ & 20 & $\begin{array}{l}16.6 \\
6\end{array}$ & 62.5 & $\begin{array}{l}33.3 \\
3\end{array}$ & $\begin{array}{l}76.6 \\
6\end{array}$ & $\begin{array}{l}66.6 \\
6\end{array}$ & $\begin{array}{l}93.3 \\
3\end{array}$ & 70 & - \\
\hline $\begin{array}{ll}\text { E. } & \text { coli } \\
(8) & \end{array}$ & 100 & 100 & 87.5 & 87.5 & 62.5 & 75 & 50 & 0 & 50 & 37.5 & 50 & 62.5 & 100 & 62.5 & - \\
\hline $\begin{array}{l}\text { C. } \\
\text { freundii( } \\
4)\end{array}$ & 100 & 100 & 75 & 75 & 0 & 25 & 25 & 0 & 50 & 25 & 100 & 25 & 50 & 75 & - \\
\hline $\begin{array}{l}P . \\
\text { mirabilis } \\
\text { (2) }\end{array}$ & 100 & 100 & 50 & 50 & 0 & 0 & 0 & 0 & 0 & 0 & - & 50 & 0 & 50 & - \\
\hline $\begin{array}{l}\text { A. } \\
\text { baumann } \\
\text { ii (77) }\end{array}$ & - & - & 100 & 100 & - & 100 & $\begin{array}{l}62.3 \\
3\end{array}$ & $\begin{array}{l}32.4 \\
6\end{array}$ & $\begin{array}{l}87.0 \\
1\end{array}$ & $\begin{array}{l}75.3 \\
2\end{array}$ & $\begin{array}{l}80.5 \\
1\end{array}$ & $\begin{array}{l}93.5 \\
0\end{array}$ & $\begin{array}{l}93.5 \\
0\end{array}$ & - & - \\
\hline $\begin{array}{l}\text { A. lwoffi } \\
\text { (4) }\end{array}$ & - & - & 100 & 100 & - & 75 & 50 & 0 & 100 & 50 & 50 & 75 & 100 & - & - \\
\hline $\begin{array}{l}P . \\
\text { aerugino } \\
\text { sa }(54)\end{array}$ & - & - & $\begin{array}{l}85.1 \\
8\end{array}$ & - & & $\begin{array}{l}81.4 \\
8\end{array}$ & $\begin{array}{l}37.0 \\
3\end{array}$ & $\begin{array}{l}12.9 \\
6\end{array}$ & $\begin{array}{l}46.2 \\
9\end{array}$ & $\begin{array}{l}51.8 \\
5\end{array}$ & - & $\begin{array}{l}81.4 \\
8\end{array}$ & - & $\begin{array}{l}81.4 \\
8\end{array}$ & 0 \\
\hline
\end{tabular}




\begin{tabular}{|l|l|l|l|l|l|l|l|l|l|l|l|l|l|l|l|}
\hline $\begin{array}{l}\text { Gram- } \\
\text { positive }\end{array}$ & $\begin{array}{l}\text { PE } \\
\text { N }\end{array}$ & $\mathbf{C X}$ & $\mathbf{E}$ & $\mathbf{C D}$ & $\begin{array}{l}\text { GE } \\
\mathbf{N}\end{array}$ & $\begin{array}{l}\text { AM } \\
\text { K }\end{array}$ & $\begin{array}{l}\text { TE } \\
\text { T }\end{array}$ & $\begin{array}{l}\text { CH } \\
\text { L }\end{array}$ & $\mathbf{C I P}$ & $\mathbf{R I F}$ & $\mathbf{L Z}$ & $\begin{array}{l}\text { VA } \\
\text { N }\end{array}$ & $\begin{array}{l}\text { OX } \\
\text { A }\end{array}$ & - & - \\
\hline $\begin{array}{l}\text { S. aureus } \\
(23)\end{array}$ & 86.9 & 39.1 & 60.8 & 39.1 & 69.5 & 26.0 & 65.2 & 4.34 & 78.2 & 0 & 0 & 0 & 39.1 & - & - \\
\hline
\end{tabular}

\section{Result:-}

Of the 302 patients, VAP rate was found to be 2.06 cases per 1000 ventilator days. A. baumannii $(38.11 \%)$ was the commonest organism isolated followed by $P$. aeruginosa $(26.74 \%)$ and $K$. pneumoniae $(14.85 \%)$. S. aureus (11.39\%) was the most common gram-positive bacteria associated with VAP. Table I shows organisms isolated from VAP cases along with their antibiotic resistance pattern.

VAP - Ventilator-associated pneumonia AMP - Ampicillin, AMC - Amoxyclav, CAZ - Ceftazidime, CTX Cefotaxime, CX - Cefoxitin, CPM-Cefipime, PIT - Piperacillin-tazobactam, MEM - Meroenem, GEN Gentamicin, AMK - Amikacin, TET - Tetracycline, CIP - Ciprofloxacin, COT - Cotrimoxazole, AT - Aztreonam, CL - Colistin, PEN - Penicillin, ERY - Erythromycin, CHL - Chloramphenicol, RIF - Rifampicin, LZ - Linezolid, VAN - Vancomycin, OXA - Oxacillin.

*Colistin resistance was detected by MIC using agar dilution method

Non-fermenters (66.83\%) were the most predominant pathogens causing VAP, members of Enterobacteriaceae and gram-positive bacteria (S. aureus) causing VAP were $42.99 \%$ and $11.38 \%$ respectively. VAP episodes due to grampositive bacteria (11.38\%) were relatively less common as compared to gram-negative bacilli $(88.61 \%)$.

\section{Detection of ESBL, AmpC $\beta$-lactamase and Metallobetalactamase}

ESBL production was detected in $25 \%$ of Enterobacteriaceae isolates and $12.59 \%$ of the Non-fermenters. AmpC $\beta$ lactamases were produced by $34.09 \%$ and $4.44 \%$ of the members of Enterobacteriaceae and non-fermenters respectively. MBL production was seen in $11.36 \%$ of the Enterobacteriaceae isolates while $14.81 \%$ of the nonfermenters were MBL producers (Table II).

Table II:- ESBL, AmpC $\beta$ - lactamase and MBL production among the gram-negative bacteria

\begin{tabular}{|l|l|l|l|}
\hline Bacteria (n) & ESBL & $\begin{array}{l}\text { AmpC } \\
\text { lactamase }\end{array}$ & MBL \\
\hline Klebsiella pneumoniae (30) & 9 & 12 & 5 \\
\hline Escherichia coli (8) & 2 & 2 & 0 \\
\hline Citrobacter freundii (4) & 0 & 0 & 0 \\
\hline Proteus mirabilis (2) & 0 & 0 & 0 \\
\hline Acinetobacter baumannii (77) & 15 & 4 & 17 \\
\hline Acinetobacter lwoffi (4) & 0 & 0 & 0 \\
\hline Pseudomonas aeruginosa (54) & 2 & 2 & 3 \\
\hline
\end{tabular}

ESBL - Extended spectrum $\beta$-lactamase, MBL - Metallo- $\beta$-lactamase

\section{Detection of MRSA}

MRSA were found to be $39.13 \%$ by oxacillin MIC testing by agar dilution method. The results of both the methods i.e. cefoxitin susceptibility testing by disk diffusion method and oxacillin MIC testing by agar dilution method, are similar. Thus, among 23 S. aureus isolates studied, nine (39.13\%) were found to be MRSA and 14 (60.86\%) were MSSA.

\section{Discussion:-}

VAP is an important nosocomial infection among ICU patients receiving MV along with multi-drug resistant pathogens causing VAP are a major concern in any kind of ICU set up. The rate of VAP obtained in our study is 2.06 cases per 1000 ventilator days similar to a study conducted by Bowton DL et al. ${ }^{23}$ However, a study by Panwar et $\mathrm{al}^{24}$ reported the VAP rate as 26 per 1000 ventilator days. 
A. baumannii (38.11\%) was the commonest isolate followed by $P$. aeruginosa $(26.74 \%)$ and $K$. pneumoniae (14.85\%). Other organisms were S. aureus (11.39\%), E. coli (3.96\%), Citrobacter freundii (1.98\%), A. lwoffi $(1.98 \%)$ and Proteus mirabilis (0.99\%). Our findings were similar to the study done by Dey A and Bairy I. ${ }^{9}$

Most of the Enterobacteriaceae isolates were sensitive to meropenem, piperacillin-tazobactum and amikacin; most non-fermentors being sensitive to piperacillin-tazobactum and colistin; and $S$. aureus being sensitive to vancomycin. Thus, the use of these antibiotics can be advocated in our area. This finding also emphasises the need for stringent preventive measures for VAP, as the treatment of an established VAP becomes very expensive. ${ }^{25}$

We observed that the most effective antibiotic for gram negative isolates was meropenem, while for S.aureus isolates was vancomycin. Piperacillin-tazobactam was highly active against Acinetobacter spp., while colistin has good activity against Pseudomonas spp. Our findings were similar to the other studies. ${ }^{26,27,28}$

MBL was produced by most of the non-fermenters, especially A. baumannii consistent with other studies. ${ }^{29}$ Some $K$. pneumoniae isolates also showed MBL production similar to a study by Galani et al. ${ }^{30}$ Similarly ESBL and AmpC $\beta$-lactamases were produced by a large proportion of the Enterobacteriaceae ${ }^{25} \mathrm{We}$ found $39.13 \%$ MRSA amongst $S$. aureus isolates. Mathews $e t a l^{21}$ reported $34.4 \%$ MRSA while Alqurashi et $a l^{26}$ reported 40\% MRSA in their studies. These isolates also shown cefoxitin resistance by Kirby-bauer disk diffusion method. A study by Arora et $\mathrm{al}^{31}$ shown that by cefoxitin disk, oxacillin screen agar and MIC testing, methicillin resistance was detected in 115 (46\%) strains. CLSI ${ }^{12}$ also states the same and advocates the use of cefoxitin disk diffusion testing, MIC to oxacillin by agar dilution and oxacillin screen agar for deciding oxacillin resistance.

The presence of these MDR pathogens highlights the need for treatment of the VAP cases with second-line antibiotics effective against them.

When the results of our study were compared with the findings of other studies, it was clear that the incidence of VAP and its resistance pattern have been changing with due course of time. Geographical variation and difference in patient population studied could be the possible factor for variability. The emergence of multi-drug-resistant pathogens causing VAP has made its treatment very difficult and, in some cases, impossible. The observed high number of GNB showing ESBL, AmpC, MBL production; S. aureus with methicillin resistance in VAP cases reflects its emerging resistance pattern. Thus, the antimicrobial policy needs to be updated from time to time.

Early diagnosis of VAP along with their sensitivity pattern will help as an epidemiological marker for initial prophylaxis and treatment planning for mechanically ventilated patients. In recent years, there has been a rapid increase in the incidence of VAP among the patients admitted to the ICUs for various clinical conditions and so is the increase in the multi-drug resistant pathogens due to their prolonged stay in the ICU leading to increased mortality and morbidity.

Hence, it is the hour of need to prevent ventilator associated pneumonia caused by hospital-acquired multi-drug resistant strains by formulating appropriate hospital antibiotic policy and proper infection control practices.

\section{References:-}

1. Ranjan N, Chaudhary U, Chaudhry D, Ranjan KP. Ventilator-associated pneumonia in a tertiary care intensive care unit: Analysis of incidence, risk factors and mortality. Indian Journal of Critical Care Medicine. 2014; 18(4): 200-4.

2. Chastre J and Fagon JY. Ventilator-associated pneumonia. Am J RespirCrit Care Med. 2002; 165: 867-903.

3. Morehead RS and Pinto SJ Ventilator-associated pneumonia. Arch Intern Med. 2000; 160: 1926-36.

4. Joseph NM, Sistla S, Dutta TK, Badhe AS, Parija SC. Ventilator-associated pneumonia in a tertiary care hospital in India: incidence and risk factors. J Infect Dev Ctries. 2009; 3: 771-77.

5. Fagon JY, Chastre J, Hance AJ, Montravers P, Novara A, Gibert C. Nosocomial pneumonia in vSentilated patients: a cohort study evaluating attributable mortality and hospital stay. Am J Med.1993; 94: 281-88.

6. Crouch Brewer S, Wunderink RG, Jones CB, Leeper KV. Ventilator-associated pneumonia due to Pseudomonas aeruginosa. Chest.1996; 109: 1019-29.

7. Rello J, Quintana E, Ausina V, Castella J, Luquin M, Net A, and Prats G. Incidence, etiology, and outcome of nosocomial pneumonia in mechanically ventilated patients. Chest.1991; 100: 439-44.

8. Fagon JY, Chastre J, Vuagnat A, Trouillet JL, Novara A and Gibert C. Nosocomial pneumonia and mortality among patients in intensive care units. JAMA.1996; 275: 866-69. 
9. Dey A and Bairy I. Incidence of multidrug-resistant organisms causing ventilator-associated pneumonia in a tertiary care hospital: A nine months' prospective study. Ann Thorac Med. 2007; 2(2): 52-7.

10. Collee JG, Duguid JP, Fraser AG, Marmion BP, Simmons A. Laboratory strategy in the diagnosis of infective syndromes. In Collee JG, Fraser AG, Marmion BP, Simmons A (eds.). Mackie and McCartney Practical Medical Microbiology, $14^{\text {th }}$ Ed, Churchill Livingstone, Delhi, 2007; p 53 -94.

11. Apostolopoulou E, Bakakos P, Katostaras T, Gregorakos L. Incidence and risk factors for ventilator-associated pneumonia in 4 multidisciplinary intensive care units in Athens, Greece. Respir Care. 2003; 48(7): 681-8.

12. CLSI 2013: Performance standard for Antimicrobial Susceptibility Testing; Twenty-third informational supplement; M100-S23. Vol.33 No.1 Clinical and laboratory standard institute, Wayne, Pa, USA.

13. Miles RS, Amyes SGB. Laboratory control of antimicrobial therapy. In Colle JG, Fraser AG, Marmion BP, Simmons A, eds. Mackie and McCartney. Practical Medical Microbiology. 14th ed; New York: Churchill Livingstone.1996; 151-78.

14. Singhal S, Mathur T, Khan S, Upadhyay DJ, Chugh S, Gaind R, Rattan A. Evaluation of methods for AmpC betalactamase in Gram negative clinical isolates from tertiary care hospitals. Ind J Med Microbiol. 2005; 23(2): 120-4.

15. Joseph NM, Menezes GA, Harish BN, Sujatha S, Parija SC. Simple screening tests for detection of carbapenemases in clinical isolates of non-fermentative Gram-negative bacteria. Indian J Med Res 2009; 129: 707-12.

16. Forbes BA, Sahm DF, Weissfeld AS. Laboratory methods and strategies for antimicrobial susceptibility testing. In Bailey and Scott's Diagnostic Microbiology, $12^{\text {th }}$ Ed, Mosby, Missouri, 2007, p 187-214.

17. Hemalatha V, Sekar U, Kamat V. Detection of metallo-betalactamase producing Pseudomonas aeruginosa in hospitalized patients. Indian J Med Res. 2005; 122(2): 148-52.

18. Picao RC, Andrade SS, Nicoletti AG, Campana EH, Moraes GC, Mendes RE et al. Metallo- $\beta$-Lactamase detection: comparative evaluation of double-disk synergy versus combined disk tests for IMP-, GIM-, SIM-, SPM-, or VIMproducing isolates. J Clin Microbiol. 2008; 46(6): 2028-37.

19. Yong D, Lee K, Yum JH, Shin HB, Rossolini GM, Chong Y. Imipenem-EDTA disk method for differentiation of metallo- $\beta$-lactamase producing clinical isolates of Pseudomonas spp. and Acinetobacter spp. J ClinMicrobiol. 2002; 40(10): 3798-3801.

20. Skov R, Smyth R, Larsen AR, Bolmstrtm A, Karlsson A, Mills K, Frimodt-moller N, Kahlmeter G. Phenotypic detection of methicillin resistance in Staphylococcus aureus by disk diffusion testing and Etest on Mueller-Hinton agar. J Clin Microbiol. 2006; 44: 4395-9.

21. Mathews A, Thomas M, Appalaraju B, Jayalakshmi J. Evaluation and comparison of tests to detect methicillin resistant S. aureus. Indian J Pathol Microbiol. 2010; 53: 79-82.

22. Mohansoundaram KM, Lalitha MK. Comparison of phenotypic versus genotypic methods in the detection of Methicillin resistance in Staphylococcus aureus. Indian J Med Res. 2008; 127: 78.

23. Bowton DL, Hite RD, Martin RS, Sheretz R. The impact of hospitalwide use of a tapered cuff endotracheal tube on the incidence of ventilator-associated pneumonia. Respir Care. 2013; 58(10): 1582-87.

24. Panwar R, Nagar VS, Deshpande AK. Incidence, clinical outcome, and risk stratification of ventilator-associated pneumonia-a prospective cohort study. Indian J Crit Care Med. 2005; 9(4): 211-16.

25. Joseph N, Sistla S, Dutta T, Badhe A, Rasitha D, Parija S. Ventilator-associated pneumonia in a tertiary care hospital in India: role of multi-drug resistant pathogens. The Journal Of Infection In Developing Countries. 2010; 4 (04): 218 25 .

26. Alqurashi AM. Antibiotic susceptibility patterns of different bacteria isolated from patients with ventilator associated pneumonia (VAP). Journal of Family and Community Med. 2005; 12(3): 139-44.

27. Ali Abdel Rahim KA and Ali Mohamed AM. Prevalence of extended spectrum $\beta$-lactamase producing Klebsiella pneumoniae in Clinical Isolates. Jundishapur J Microbiol. 2014; 7(11): 1-5.

28. Duran N, Ozer B, Duran G, Onlen Y, Demir C. Antibiotic resistance genes \& susceptibility patterns in staphylococci. Indian J Med Res. 2012; 389-96.

29. Gopalkrishnan R, Dorairajan S. Changing trends in antimicrobial susceptibility and hospital acquired infections over an 8 year period in a tertiary care hospital in relation to introduction of an infection control programme. $\mathrm{J}$ Assoc Physician India, 2010; 58: 25-31.

30. Galani I, Rekatsina PD, Hatzaki D et al. Evaluation of different laboratory tests for detection of metallo- $\beta$ lactamase production in Enterobacteriaceae. J Antimicrob Chemotherapy 2008; 25: 1-6.

31. Arora S, Devi P, Arora U, Devi B. Prevalence of methicillin-resistant Staphylococcus aureus (MRSA) in a tertiary care hospital in Northern India. J Lab Physicians. 2010; 2: 78-81. 